\title{
LIGHT AND SCANNING ELECTRON MICROSCOPY ON MONOGENEAN PARASITE FROM RED SEA FISH NEMIPTERUS JAPONICUS (TRIEADIN BRAENS) IN EGYPT
}

\author{
SAMAR W. TADROS ${ }^{*}$ AMAL K. EL-GAYAR ${ }^{* *}$ and GHADA M. MOHAYEMEN ${ }^{* * *}$ \\ * Animal Health Research Institute, Port Said branch, Parasitology Unit. \\ ** Department of Parasitology, Faculty of Veterinary Medicine, Suez Canal University \\ *** Animal Health Research Institute, Fish Disease Department, Fish Parasites Unit. \\ Email: samarhesham@,rocketmail.com
}

\begin{tabular}{ll}
\hline & ABSTRACT \\
\hline \multirow{2}{*}{ Received at: 26/2/2014 } & During a survey from November 2012 till October 2013 on a marine fish's species \\
& Nemipterus japonicas, a microcotylid monogenean species Lutianicola \\
Accepted: $\mathbf{3 / 4 / 2 0 1 4}$ & haifonensis was recorded for the first time from 42 out of 80 (52.5\%) examined \\
& fish's species in Red Sea. Nemipterus japonicas were found to be recorded as a \\
& new host for both the monogenea and crustacean parasite species. A copepod \\
& crustacean, Hatschekia gracilis also recorded for the first time from 16 out of 80 \\
& (20\%) of $N$. japonicas fishes. A brief description for Lutianicola haifonensis and \\
& Hatschekia gracilis was presented. Scanning electron microscopy (SEM) for L. \\
& haifonensis is studied.
\end{tabular}

Key words: Monogenea- marine fish-electron microsope- Nemipterus japonicus (Trieadin braens), Microcotylid, Hatschekia

\section{INTRODUCTION}

Marine fisheries are of lesser production to Egypt than its major freshwater fisheries and aquaculture industries, and represent only about $17 \%$ of total fish production in Egypt. However, of the marine fisheries, approximately $55 \%$ of the total marine fish catched comes from the Red Sea and Gulf of Suez (FAOLex, 2004). Most studies of monogenean parasites in Egypt were carried out on freshwater fishes (Khidr, 1997; El-Naggar et al., 2001; ElNaggar \& El-Abassy, 2003). Little attention has paid to parasites of marine fish, especially monogenetic trematodes except that carried by Paperna (1972a,b,c); Bayoumy, (2003), Bayoumy et al. (2007) and Bayoumy and Abd El-Monem (2011). During a recent assessment of Red sea fish species by the animal Health Research Institute (Port-Said branch), a samples of Nemipterus japonicas (Trieadin braens) was found to be infected with a microcotylid monogenean parasite, whose morphology is consistent with a Microcotyle omanae, which was firstly described from the gill of Cheimerius nufar from Arabian Sea (Machkewskyi et al., 2013). The Microcoylidae is the largest family in monogenean subclass Oligonchoinea Bychowsky, 1937. At the present some 150 species belonging to more than 40 genera were counted within this family. However, the specific composition and status of some genera remain obscure up to now (Mamaev, 1986).

Scanning electron microscopy provide resolution at high magnification, which has been exploited in helminthology to elucidate and describe the specialized organs of attachment, the position of oral and genital apertures considered as additional diagnostic and taxonomic characters (Ramasamy et al., 1995; Ramasamy and Brennean 2000; Bayoumy et al., 2007 and Yoon et al., 2013).

Nevertheless, different species of Monogenea may present ultrastructural variations of the tegument, such as presence of microvilli and secretory pores and a wide variation in morphological aspect of surface modifications and sensory structures (Smyth and Halton 1983). Therefore, it is important to investigate the tegument of each individual species in order to elucidate questions on maintenance and survival of the parasite on their microhabitat. In Microcotylidae, the tegument of Atriaster sp. and Microcotyle sp. has been studied by transmission electron microscopy (TEM) (Justine and Bonami 1993). The gills are a favorite site for the attachment of several parasitic copepods. They damage the gills by feeding on the delicate tissue of the gill lamellae or on the blood circulating within the lamellae, leading to a loss of respiratory surface area (Pillai, 1985; Lester and Hayward, 2006; Purivirojkul and Areechon, 2008). Lutianicola haifonensis species is described for the first time from Nemipterus japonicus (Trieadin braens) in the Al Ghardaqa, Red Sea, Egypt. The copepod family Hatschekiidae Kabata, 1979 consists of eight genera known as gill parasites of marine teleost fishes (Boxshall and Halsey 2004). Of these, Hatschekia Poche, 1902 is the largest genus of the family, containing 97 valid species found on the gills of nearly 140 actinopterigian fish species (Uyeno and Nagasawa 2010).

\section{MATERIALS and METHODS}

80 specimens of Nemipterus japonicus, (Trieadin braens), 30-34 cm in total length, and weight 300 - 
500 gm were caught in the Red Sea off al- Ghardaqah $\left(27^{\circ} 15^{\prime} 28^{\prime \prime} \mathrm{N} 33^{\circ} 48^{\prime} 42^{\prime \prime} \mathrm{E}\right)$ Red sea Governorate, from November 2012 till October 2013 and identified using Randall (1995) and Abd-essalaam (1995). The fish specimens were transported to the Laboratory of animal Health Research institute (Port-Said branch) in an ice box to be examined. The gills removed in small Petri dishes containing 0. 9\% NACL to get rid excess mucus. For light microscopy, the isolated parasites were fixed in 5\% formal saline and washed with distilled water to remove excess fixative. For staining acetic acid alum carmine was used according to (Carleton, 1967) for 10-30 minutes. Dehydration was maintained by passing in ascending grads of ethyl alcohol, cleared in clove oil and mounted in Canada balsam. All dimensions are given in micrometers as the mean, with the range and number of measurements in parentheses.

\section{Parasites specimens for SEM}

10 parasitic fish specimens were used in this study. Worms were collected and prepared for SEM as follows. Living specimens were kept for 30 minutes in the refrigerator before fixation in $4 \%$ aqueous gluteraldehyde solution at $4{ }^{\circ} \mathrm{C}$ for $48 \mathrm{hrs}$. (Halton, 1979). Then the specimens washed thoroughly with cacodylate buffer and post fixed for $4 \mathrm{hrs}$. With aqueous osmium tetroxide (OsO4), dehydrated through acetone, dried in Polaron Equipmement, E300 critical point drying apparatus using liquid $\mathrm{CO} 2$, mounted on aluminum stub with double phase sticker. The specimens then coated with goldpalladium in an E5000 sputter coating unit (Polaron Equipment) coating unit and examined in a Joel SEM T330 scan-electron microscope operating at $20 \mathrm{Kev}$.

\section{For copepods collection:}

All gill arches from both sides were removed one by one by cutting them at their extremities and examined immediately in seawater. Parasites were collected under a binocular microscope.

Copepods were removed with fine forceps or with the help of a fine needle, or brush and immediately fixed in $70 \%$ ethanol. Copepod identification was based on morphological features according to Yamaguti (1963); Kabata (1979); Pillai (1985).

\section{RESULTS}

\section{1- Lutianicola haifonensis}

Class: Monogenea Carus, 1863

Family: Microcotylidae Taschenberg, 1879

Subfamily Microcotylinae Monticelli, 1892

Site: Gill of 50 fish specimens out of $80(62 \%)$

Host: Nemipterus japonicus (Trieadin braens)

Locality: al- Ghardaqah $\left(27^{\circ} 15^{\prime} 28^{\prime \prime} \mathrm{N} 33^{\circ} 48^{\prime} 42^{\prime \prime} \mathrm{E}\right)$, Red sea Governorate

\section{Light microscopy}

Body; lanceolate, elongate (Fig I,1) body length,4,400-5,900 $\mu \mathrm{m}$, haptor length, (2750-7375 $\mu \mathrm{m}) ; 585 \mu \mathrm{m}(275-775 \mu \mathrm{m})$ in maximum width at the level of the germarium. No terminal anchors present. Paired muscular, unarmed, septate buccal organs (Fig. I, 2). Oesophagus simple without diverticula. Oesophagus $134 \mu \mathrm{m}(100-175 \mu \mathrm{m})$ long. Intestinal caeca terminates post-testicular in the narrow peduncle leading to the haptor. Genital atrium muscular, unarmed $85 \mu \mathrm{m}(75-90 \mu \mathrm{m})$ wide, $84 \mu \mathrm{m}$ $(75-100 \mu \mathrm{m})$ long at its base; projects away from the body as a small cone. Two large, paired, muscular, dorsal, vaginae, unarmed. Large, fusiform, operculated eggs (275-310) $\mu \mathrm{m}$ long, 85-108 $\mu \mathrm{m}$ wide (present in 4 specimens). Very long, tangled, apical filament $\sim 1060 \mu \mathrm{m}$ long, which tapers towards its extremity, the terminus of which is not thickened; posterior filament $110 \mu \mathrm{m}$ long (Fig. I, 3). Testes numerous, post-ovarian $42 \mu \mathrm{m}(45-55)$ in number, situated in post-ovarian intercaecal field, not extending into the haptoral penduncle. Conspicuous Y-shaped vitelline duct, irregular, well defined, darkbrownish in coloration, co-extensive with intestinal caecae, extending from the genital atrium to mid-way along the haptoral peduncle (Fig. I, 4), branches 191 $\mu \mathrm{m}(185-200 \mu \mathrm{m})$ long, the posterior piece $242 \mu \mathrm{m}$ $(230-255 \mu \mathrm{m})$ long, leads into the genito-intestinal canal. Haptor symmetrical, with numerous clamps arranged in two equal rows of approximate equal size containing 98-135 of clamps arranged in two equal rows (Fig. I, 5a). Clamps, of approximate similar shape but size slightly dissimilar; clamps develop in a posterior to anterior direction (Fig. I, 5b).

\section{Scanning electron microscopy:}

The body of Lutianicola haifonensis is elongated, with a posterior haptor (Fig. $\Pi, 6$ ). The buccal cavity and the opening of the genitalatrium lie in the anterior part of the ventral surface (Fig $\Pi, 7$ ). The tegument of the body presents regular intervals, forming folds in the ventral and dorsal surfaces (Fig. П, 7). It presents microvillous-like tegumental projections, covering both ridges and folds (Fig. $\Pi, 8$ ). Isolated, papillae were observed irregularly distributed all over the body surface (Fig. $\Pi, 8$ ). The tegument around the opening of genital atrium is folded, and contains microvillous-like projections and non-ciliated sensory papillae (Fig. П, 8).

The haptor is separated from the body proper at the posterior region. It is triangular and composed of two symmetrical rows of clamps, formed by two opposable hinged jaws and covered by a thin tegument. The internal margins of the clamps are serrated and, depending on state of contraction, may be opened or closed (Fig. $\Pi, 9$ ). The haptoral tegument is similar to the rest of the body, differing only in the fact that the microvillous- like projections are absent.

\section{2- Copepods}

Hatschekia gracilis Yamaguti, 1954

Habitat and locality. Gill of Nemipterus japonicus

(Trieadin braens), Red Sea

Material. Five mature females. 
Body slender, 1.9-2.1 mm long (Fig. ПI, 10, 11). Head cordate, 0.175-0.2 mm in length, 0.16-0.19 mm in maximum breadth near posterior margin which is slightly convex and partly covers the first thoracic segment. Frontal plate prominent, flattened conical or semicircular, projecting a little beyond the bases of first antennae. Who's ventrally directed stem turns inward at the point where it gives rise to a rudimentary side branch. The median rib as well as the two arms terminate in a sharp point at the level of the broadest part of the head. On the ventral side of the head just behind the base of each second antenna there is a fleshy, not very sharp-pointed process applied to the antenna. First thoracic segment forming neck. Genital segment slender, 1.6-1.8 $\mu \mathrm{m}$ in length, $0.18-0.2 \mu \mathrm{m}$ in maximum breadth at its posterior third. Abdomen semicircular, 18-24, $\mu \mathrm{m}$ by $50-63$ $\mu \mathrm{m}$. Caudal rami small, $15-18 \times 7-8 \mu \mathrm{m}$, attached to ventral side of abdomen. Two egg sacs cigarette shaped (Fig. ПI, 12), 0.62-0.95 $\mu \mathrm{m}$ long, each containing a series of about ten or more eggs. First antenna 84-90 $\mu \mathrm{m}$ long, tapering gradually toward distal end, without distinct joints except the basal which occupies almost half the entire length. Maxilla represented by a simple seta. Mandible slender, without teeth. Maxilliped 4-segmented; third segment a little shorter than second one; terminal claw bifid. First and second legs biramose; exopods two segmented but endopods one segmented. Proximal segments of first and second exopods with a terminal spine at each distal outer end. Distal segment of first exopod with 5 setae, of which two are at the tip, and the other three along distal inner margin; first endopod with 5 setae including the one at middle of inner margin. Second exopod with three terminal setae; second endopod with two setae on inner margin and four at tip. Third legs absent.

Table 1: Comparative metrical data for Lutianicola hofenensis and for morphologically closely related species of Microcotyle from the Indo-Pacific region

\begin{tabular}{|c|c|c|c|c|c|c|}
\hline & $\begin{array}{l}\text { Lutianicola } \\
\text { haefonensis }\end{array}$ & $\begin{array}{c}\text { Microcotyle } \\
\text { omanae }\end{array}$ & $\begin{array}{c}\text { Microcotyle arripis } \\
\text { Sandars } 1944 \\
\end{array}$ & $\begin{array}{c}\text { Microcotyle helotes } \\
\text { Sandars } 1944\end{array}$ & $\begin{array}{c}\text { Microcotyle caudate } \\
\text { Goto, } 1984\end{array}$ & $\begin{array}{l}\text { M. sebastis } \\
\text { Goto, } 1984\end{array}$ \\
\hline Hosts & $\begin{array}{l}\text { Nemipterus } \\
\text { japonicas }\end{array}$ & $\begin{array}{c}\text { Cheimerius } \\
\text { nufar }\end{array}$ & $\begin{array}{c}\text { Arripis } \\
\text { georgianus }\end{array}$ & $\begin{array}{c}\text { Pelates sexlineatus; } \\
\text { Pelsartia humeralis; } \\
\text { Therapon theraps }\end{array}$ & $\begin{array}{c}\text { Helicolenus } \\
\text { dactylopterus; } \\
\text { Setarches longiceps }\end{array}$ & Sebastes spp. \\
\hline locality & Red Sea & Arabian Sea & $\begin{array}{l}\text { Western } \\
\text { australia }\end{array}$ & $\begin{array}{c}\text { Western australia; } \\
\text { Southeast Indian Ocean; } \\
\text { South China Sea }\end{array}$ & $\begin{array}{c}\text { Southwest Indian } \\
\text { Ocean; }\end{array}$ & $\begin{array}{c}\text { East China Sea } \\
\text {;yellow Sea }\end{array}$ \\
\hline Source & Present study & $\begin{array}{l}\text { Machkewskyi } \\
\text { et al., } 2013\end{array}$ & 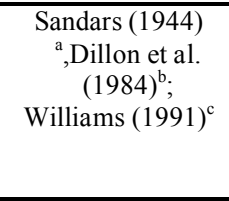 & $\begin{array}{c}\text { Dillon et al. }(1984)^{b} \\
\text { Williams }\left(1991^{\mathrm{c}}\right.\end{array}$ & $\begin{array}{c}\text { MacCallum \& } \\
\text { MacCallum (1913)d; } \\
\text { Sandars (1945)a; } \\
\text { Yamaguti (1963 }\end{array}$ & $\begin{array}{c}\text { MacCallum \& } \\
\text { MacCallum (1913)d; } \\
\text { Sandars (1945)a; } \\
\text { Yamaguti (1963)e,f; } \\
\text { Radujkovic \& } \\
\text { Euzet (1989) }\end{array}$ \\
\hline Body length & $4,400-5,900$ & $3,500-11,000$ & $\begin{array}{c}2,080^{\mathrm{a}} \\
1,684-2,530^{\mathrm{b}} \\
4,347^{\mathrm{c}} \\
\end{array}$ & $\begin{array}{l}1,610-1,730^{b} \\
1,773-3,088^{c}\end{array}$ & $3,200 \mathrm{e}$ & $\begin{array}{c}5,500^{\mathrm{e}} \\
2,500-3,200^{\mathrm{g}}\end{array}$ \\
\hline $\begin{array}{l}\text { Haptor } \\
\text { length }\end{array}$ & $1,235-3,425$ & $1,125-3,225$ & $\begin{array}{c}528^{\mathrm{a}} \\
707-874^{\mathrm{b}} \\
1,287 \mathrm{c}\end{array}$ & $\begin{array}{c}610^{\mathrm{b}} \\
684-1,160^{\mathrm{c}}\end{array}$ & $800 d$ & $1,100^{\mathrm{d}}$ \\
\hline $\begin{array}{l}\text { Number of } \\
\text { clambs }\end{array}$ & $98-135$ & $94-120$ & $68-108^{b}$ & $\begin{array}{c}54-60^{\mathrm{b}} \\
37-103^{\mathrm{c}}\end{array}$ & $\begin{array}{l}52-56^{\mathrm{e}} \\
46-62^{\mathrm{f}}\end{array}$ & $\begin{array}{l}52-56^{\mathrm{c}} \\
46-62^{\mathrm{f}} \\
38-56^{\mathrm{g}} \\
\end{array}$ \\
\hline $\begin{array}{l}\text { Buccal } \\
\text { organ } \\
\text { length }\end{array}$ & $130-140$ & $60-120$ & $\begin{array}{c}64^{\mathrm{a}} \\
37-45^{\mathrm{b}} \\
41-49^{\mathrm{c}} \\
\end{array}$ & $\begin{array}{c}60^{b} \\
46-72^{c}\end{array}$ & --- & ----- \\
\hline $\begin{array}{l}\text { Pharynex } \\
\text { length }\end{array}$ & $38-85$ & $28-75$ & $\begin{array}{c}48^{\mathrm{a}} \\
38-47^{\mathrm{b}} \\
46-56^{\mathrm{c}}\end{array}$ & $\begin{array}{l}35-38^{b} \\
33-46^{c}\end{array}$ & ----- & ----- \\
\hline $\begin{array}{c}\text { Genital atrium } \\
\text { length }\end{array}$ & $75-100$ & $125-214$ & $\begin{array}{c}80^{\mathrm{a}} \\
92-103^{\mathrm{c}} \\
\end{array}$ & $72-92 c$ & ------ & $170 \mathrm{~g}$ \\
\hline $\begin{array}{l}\text { Genital } \\
\text { atrium } \\
\text { width }\end{array}$ & $75-90$ & $127-193$ & $\begin{array}{c}128^{\mathrm{a}} \\
164-201^{\mathrm{b}} \\
114-137^{\mathrm{c}}\end{array}$ & $\begin{array}{c}88^{b} \\
74-116^{c}\end{array}$ & ------ & $75 \mathrm{~g}$ \\
\hline $\begin{array}{l}\text { Testes } \\
\text { number }\end{array}$ & $45-55$ & $34-55$ & $\begin{array}{c}10-16^{b} \\
23^{a} \\
13-22^{b}\end{array}$ & $\begin{array}{l}12-13^{b} \\
9-19^{c}\end{array}$ & $\begin{array}{l}20-27^{\mathrm{c}} \\
23^{\mathrm{d}}\end{array}$ & $\begin{array}{l}36-43^{\mathrm{e}} \\
21-48^{\mathrm{f}} \\
15-17^{\mathrm{g}}\end{array}$ \\
\hline Egg length & $275-310$ & $260-300$ & $\begin{array}{c}224^{\mathrm{a}} \\
233-248^{\mathrm{b}}\end{array}$ & $234-240^{c}$ & ------ & ----- \\
\hline Egg width & $85-108$ & $75-105$ & $\begin{array}{c}80^{\mathrm{a}} \\
68-92^{\mathrm{b}}\end{array}$ & $74-80 c$ & ------ & ----- \\
\hline
\end{tabular}

a-g Data correspond to respective sources. Data from: e Yamaguti (1963) and d Goto (1984: cited by MacCallum \& MacCallum, 1913) from the Sea of Japan, f Bonham \& Guberlet (1937: cited by Yamaguti, 1963) from the NE Pacific Ocean and g Radujkovic \& Euzet (1989) from the Adriatic Sea, are used for comparison, as data for these species from Indo-Pacific are absent 

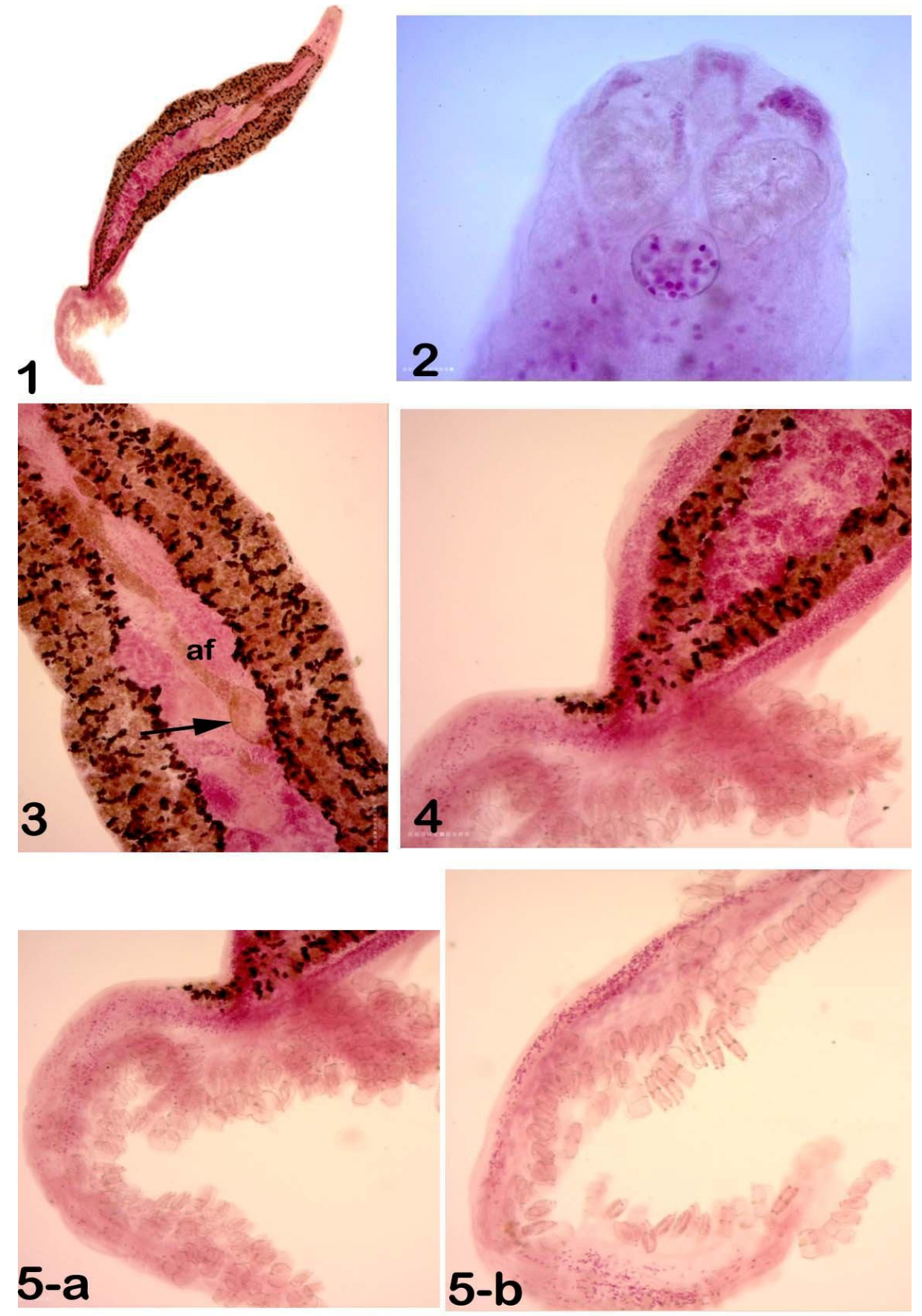

\section{Figure I :}

1- Adult of Lutianicola haifonensis x100.

2- Buccal cavity of the L. haifonensis $\mathrm{x} 400$.

3- Egg (arrow) af. Anterior filament; o. approximate position of the operculum x 200 .

4- Haptor peduncle $\mathrm{x} 200$.

5- Haptor (a) and clamp (b) $\times 200$. 
$\underline{\text { Assiut Vet. Med. J. Vol. } 60 \text { No. } 141 \text { April } 2014}$
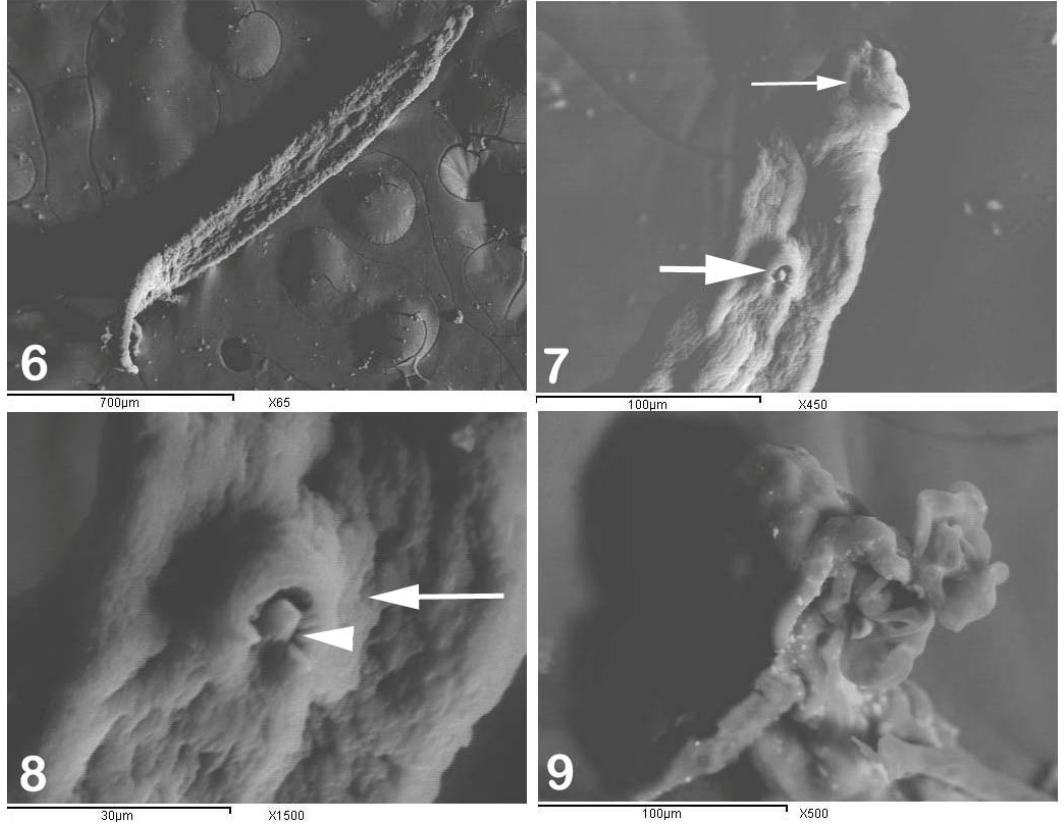

\section{Figure П:}

6- Total body x 65 .

7- Anterior region of body with subterminal buccal cavity (thin arrow) and the opening of genital atrium (thick arrow) $\mathrm{x}$ 450.

8- Tegument of body showing the microvillus like tegumental projections (arrow) and sensory papillae and genital atrium (arrowhead) x1500.

9- Internal margins of the clamps x 500 .
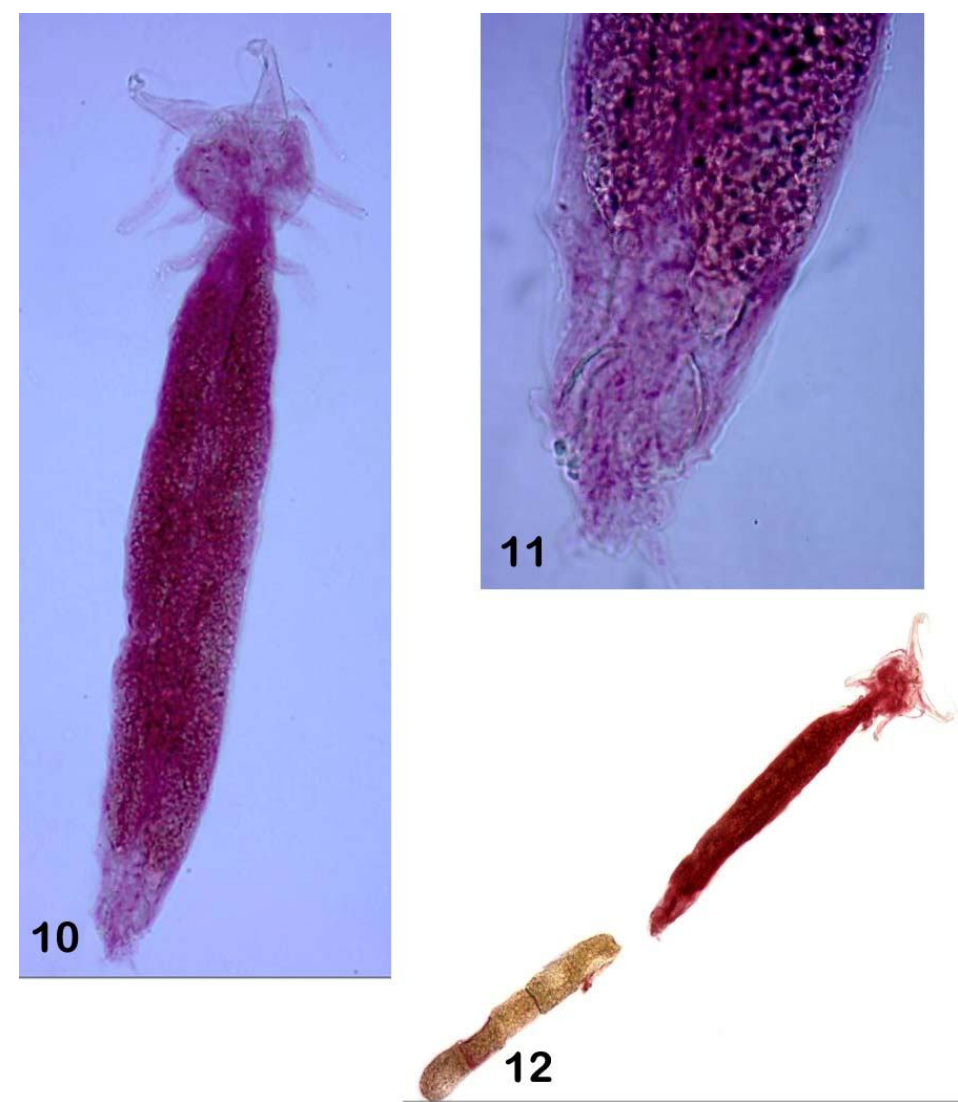

Figure ПII:

10- Adult female Hatschekia gracilis $\times 100$.

11- Posterior end of Hatschekia gracilis $\mathrm{x} 200$.

12 -Egg sacs of Hatschekia gracilis x100. 


\section{DISCUSSION}

The present study revealed that a microcotylidae Monogenea Lutianicola haifonensis from Nemipterus japonicas fish with the incidence of $52.5 \%$ which nearly agreed with Bayoumy et al. (2007), who revealed that the percentage of Polypisthocotylea; Microcotylidae; Monogenea was $48 \%$ in Diplodus noct fish but differ from the same parasite by a rate of $28 \%, 22 \%$ and $16 \%$ in Gerres oyena, Lethrinus elongates and Siganus revulatus Red sea fishes, Egypt respectively. There are 24 genera in the subfamily Microcotylinae (Shin et al., 2013), which, according to Mamaev (1986) includes microcotylids that possess a symmetric or sub-symmetric, welldelineated haptor, Lutianicola haefonensis most closely resembles Microcotyle omanae n. sp. which has been described from Cheimerius nufar in the Arabian Sea (Machkewskyi et al., 2013) it is similar in the general shape of the morphology, it differs in (1) the shorter length of genital atrium; (2) the greater length of the haptor and the number of clambs; and (3) the greater length of the eggs (Table 1). M. arripis Sandars, 1945 which has been described from Arripis georgianus (Valenciennes) in the Indian Ocean off Australia (Sandars, 1945; Dillon et al., 1984; Williams, 1991; Catalano et al., 2010). It is similar in the general shape of the genital atrium, the main proportions of the body (Table 1) and the topology of the organs. Lutianicola haefonensis differs in: (1) the greater length of the genital atrium; (2) the greater number of testes; and (3) the greater length of the eggs (Table 1). Microcotyle helotes was described from Pelates sexlineatus (Quoy \& Gaimard) off Western Australia (Sandars, 1944) and has been redescribed from the same host (Dillon et al., 1984), from Pelsartia humeralis (Ogilby) in Australian waters (Williams, 1991) and from Therapon theraps Cuvier in the South China Sea (Zhang et al., 2001). Lutianicola haefonensis can be distinguished from $M$. helotes by its greater: (1) length of the genital atrium; (2) number of testes (3) number of the clamps; and (4) length of the eggs (Table 1). Microcotyle caudata Goto, 1894 and M. sebastis Goto, 1894, described from Sebastis spp. off the coast of Japan (Yamaguti, 1963), and also recorded from the Indian Ocean (Parukhin, 1989) and the South China Sea (Kim et al., 2001), have some similarities with L. haefonensis in the shape of the genital atrium. However, $L$. haefonensis differs from both species in its greater number of clamps. L. haefonensis can also be differentiated from M. caudata by its greater number of testes and from M. sebastis by its greater haptor length (Table 1). Moreover, L. haefonensis morphologically closely related congeners (Table 1). Body size on its own is not an adequate diagnostic character, as it can depend on parasite age, host size, environmental factors and even on the degree of flattening of the worms during preparation. Among the species of Microcotyle known from other regions, M. donavini van Beneden \& Hesse, 1863, M. erythrini van Beneden \& Hesse, 1863 and $M$. fusiformis Goto, 1894 appear similar to the $L$. haefonensis in the shape of the genital atrium. However, L. haefonensis differs from all of these species in its greater number of testes $(45-55$ vs but 18-22 in M. donavini, 16-29 in M. erythrini and 15 in M.fusiformis). It can be further distinguished from $M$. donavini by the shorter length of the genital atrium $(75-100$ vs $250 \mathrm{~lm})$ and the greater length of the eggs; and from M. fusiformis by the greater number of clamps (98-135 vs 60-66) (Radujkovic \& Euzet, 1989 and Yamaguti, 1963). Lutianicola haifonensis firstly described by Lebedev 1970 from Lutianus russeli in Russian and redscribed by Mamaev, (1986) as the parasite of fishes of the genus Lutianus. The vaginae of Lutianicola haifonensis are paired, unarmed and lateroventral in positioned (Mamaev, 1986) and this differ from species belonging to the genus Microcotyle van Beneden et Hesse, 1863, which have a single, typically mid-dorsally positioned, vagina that is unarmed. Lutianicola haifonensis differ from Omanicotyle heterospina in that the latter have two large, paired, muscular, dorsal, vaginae, each armed with a crown of robust equal sized spines (Yoon et al., 2013). The following genera have both an armed genital atrium and an armed cirrus: Caballeraxine; Diplostamenides; Lutianicola; Neobivagina; Neobivaginopsis; Pseudobivagina; Pseudoneobivagina; Ciaenacotyle; and Sebasticotyle, whilst species belonging to the genera Diplasiocotyle, Kahawaia, Jaliscia, Microcotyle, Paranaella, Polymicrocotyle and Solostamanides possess an armed genital atrium (Yoon et al., 2013). The genera Gamacallum, Magniexcipula and Monomacracanthus have an unarmed genital atrium but an armed penis/cirrus, whilst species belonging to Paramicrocotyloides, auciconfibula and Pseudoaspinatrium have both an unarmed genital atrium and unarmed cirrus. Only the genera Bivagina (Yamaguti, 1963) and Omanicotyle n. gen. (Yoon et al., 2013) have an unarmed genital atrium and no differentiated cirrus.

Ultrastructural study of the tegument of Monogenea Lutianicola hoifensis by SEM had revealed that the topography of the surface shows variations in the surface architecture, most of them with functional significance. In our specimens, microvillous-like tegumental projections were observed in anterior and middle regions of body. These structures are characteristic of the tegument of the majority of the species studied, including Diclidophora merlangi (Halton 1979), M. labracis (Oliver 1981), Heterapta chorinemi (Ramasamy \& Hanna 1986b). However, they are absent in others, such as Pseudothoracocotyla indica and Bicotyle vellavoli (Ramasamy \& Hanna 1985, 1986a). The ridges and 
microvillous-like projections present in the tegument increase the surface area, suggesting metabolic exchange (Oliver 1981) and absorption of micromolecular nutrients from the surrounding environment (Ramasamy \& Hanna 1986b). Halton (1978) suggested that the occurence of microvilli and the absorptive function of the tegument provide an evidence of a close phylogenetic relationship between Monogenea and Cestoda. The microvillous-like structures were observed by SEM in other species of Microcotylidae, as in M. labracis (Oliver 1981). Santos et al. (1996) referred these structures as filaments in $A$. heterodus. The distribution of microvillous-like projections in the tegument of $P$. luquei is uniform on the ventral and dorsal surfaces and over the ridges and folds of the anterior and middle regions of body. These structures were not observed on the haptoral surface. This finding agrees with the suggestion of a close contact with the host tissue for attachment in the gill filaments. The microvillous like projections, if present, may cause friction in the host tissue. Any increase of the surface area in this region is obtained by pits and depressions. The presence of numerous pores on the tegument of P.luquei may indicate that the exocrine discharge occurs by means of these pores, as suggested for Polystoma integerrimum by Williams and McKenzie (1995).

The present study revealed that an incidence of $20 \%$ of Hatschekia gracilis, which nearly agreed with Purivirojkul and Areechon (2008), who recorded that prevalence of family Hatscehkiidae, Pseudocongericola sp., $22.73 \%$ in Muraensox sp., fish from the Gulf of Thailand, Chon Buri Province but lower than family Hatschekiidae, Hatschekia caudate $82.35 \%$ in Lutianus vitta fish and family Hatschekiidae, Hatschekia sp., 53.33\% in Scolopsis dubuosus fish from the Gulf of Thailand.

Numerous specimens of hatschekiids were collected. Hatschekia gracilis Yamaguti, 1954 was found on in the gills of Lethrinus sp. Lethrinus miniatus in New Caledonia serves as a host to a species of Hatschekia that closely resembles $H$. elegans as described by Kabata (1991). From L. miniatus (as L. chrysostomus Richardson) caught off Heron Island, Australia. $H$. elegans has a uniquely elongated head which carries finely spinulate protuberances on its lateral margins. The material from Nemipterus japonicus in Red Sea has the same characteristic head shape and carries spinulate protuberances laterally, but the body is considerably longer. Body length is known to vary according to the state of contraction, especially in fixed material, but until further studies are made this species is referred to as Hatschekia gracilis. This species differs from the most closely related $H$. longigenitalis (vide supra) chiefly in body size, the shape of the head and the structure of its chitinous framework, in the second antennae being dotted for the greater part and in the maxilla being a simple seta (Yamaguti 1954). The material likes the species described by Jones (1985) from Lethrinus sp. in Newzeland.

\section{CONCLUSION}

A microcotylidae Monogenea Lutianicola haifonensis was recorded for the first time from 42 out of eighty $(52.5 \%)$ examined fish specimens in Red Sea. Nemipterus japonicas were recorded to be infested and named as new host. A copepod Hatschekia gracilis in 16 out of eighty $(20 \%)$ also recorded for the first time from $N$. japonicas fish as anew host also.

\section{REFERENCES}

Al-Abdessalaam, Th.Z.S. (1995): Marine species of the Sultanate of Oman. Ministry of Agriculture and Fisheries Wealth, pp. 283-285.

Bayoumy, E.M. (2003): Monogenean parasites infecting some fishes from the Red Sea in Egypt. Ph-D. Thesis, Fac. Sci. Cairo Univ. Egypt.

Bayoumy, E.M.; Abd El Hady and O.K.; Hassanain, M.A. (2007): Light and electron microscopy of Paranella diplodae N.SP. (Polyopisthocotylea; Microcotylidae; Monogenea) from some Red Sea Teleost Fishes in Egypt. BS.Vet. Med. J. January. Vol. 17 (1):1-5.

Bayoumy, E.M. and Abd El-Monem (2011): Surface Topogaphy and Spemiogenesis of Lamellodiscus Diplodicus (monogenea, dilectanidae), a parasite of Gerres Oyena (teleostei, Gerridae) from the Suez Gulf, Egypt. Life Science. 8, (3): 467-476.

Boxshall, G.A. and Halsey, S.H. (2004): An Introduction to Copepod Diversity, Part II. The Ray Society, London, pp 422-966.

Carleton, H. (1967): Carleton's histlolgical technique Fourth, edition-Oxford, Unv. Press. New York. Toronto.

Catalano, S.R.; Hutson, K.S.; Ratcliff, R.M. and Whittington, I.D. (2010): Redescriptions of two species of microcotylid monogeneans from three arripid hosts in southern Australian waters. Systematic Parasitology, 76, 211-222.

Dillon, W.A.; Hargis, W.J.Jr. and Harrises, A.E. (1984): Monogeneans from the southern Pacific Ocean. Polyopisthocotyleids from Australian fishes. Subfamily Microcotylinae. Zoologicheskii Zhurnal, 63, 348-359. (In Russian).

FAOLex (2004): FAOLex Legal Database. http:// faolex.fao.org/faolex/index.htm.

El-Naggar, M.M. and El-Abbassy, S.A. (2003): Anatomical observations on the viviparous monogenean Gyrodactylus rysavyi Ergens, 
1973 from the catfish Clarias gariepinus in Egypt. Egypt. J. Zool., 40: 225- 249.

El-Naggar, M.M.; El-Naggar, A.M. and El-Abbassy, S.A. (2001): Microhabitat and movement of the viviparaous monogeneans Gyrodctylus alberti, Macrogyrodactylus clarii and $\mathrm{M}$. congolensis from the Nile catfish Clarias gariepinus. J. Egypt. Ger. Soc. Zool., 35: 169-187.

Justine, J.L. and Bonami, J.R. (1993): Virus-like particles in a monogenean (Plathyhelminthes) parasitic in a marine fish. Int. J. Parasitol., 23: 69-75.

Halton, D.W. (1978): Trans-tegumental absorption of alfaalanine and alfa-leucine by a monogenean Diclidophora merlangi. Parasitology 76: 29-37.

Halton, D.W. (1979): The surface topography of a monogenean, Diclidophora merlangi, revealed by scanning electron microscopy. Z. Parasitenkde., 61: 1-12.

Jones, J.B. (1985): A revision of Hatschekia Poche, 1902 (Copepoda: Hatschekiidae), parasitic on marine fishes, New Zealand Journal of Zoology, 12:2, 213-271.

Kabata, Z. (1991): Copepoda parasitic on Australian fishes, XIII - Family Hatschekiidae. Journal of Natural History, 25, 91-121.

Kabata, Z. (1979): Parasitic Copepoda of British fishes. London: Ray Society. P:468.

Khidr, A.A. (1997): Observations on egg assembly in the monogenean gill parasites Cichlidogyrus halli typicus (Price and Kirk, 1967) Paperna, 1979. J. Egypt Ger. Soc. Zool., 13: 1-17.

Kim, K.H.H.; Lee, E.H.; Kwon, S.R. and Cho, J.B. (2001): Treatment of Microcotyle sebastis infestation in cultured rockfish Sebastes schlegeli by oral administration of praziquantel in combination with cimetidine. Diseases of Aquatic Organisms, 44, 133-136.

Lebedev, B.I. (1970): Helminths of epipelagic fishes of South -China Sea. Golminty zhivot-nych Yugo. Vostochnoy Azii, Izd. Nauka, Moskva, 191-216.

Lester, R.J.G. and Hayward, C.J. (2006): Phylum Arthropoda, pp 466-565. In P.T.K., Woo. (ed.). Fish Diseases and Disorders Vol 1: Protozoan and Metazoan Infections. $2^{\text {nd }}$ edition. CAB international, London.

Machkewskyi, V.K.; Dmitrieva, E.V.; Al-Jufaili, S. and Nashwa, A.M.Al-Mazrooei. (2013): Microcotyle omanae n. sp. (Monogenea: Microcotylidae), a parasite of Cheimerius nufar (Valenciennes) (Sparidae) from the Arabian Sea. Syst Parasitol 86: 153-163.

Mamaev, Y.L. (1986): The taxonomical composition of the family Microcotylidae Taschenberg, 1879 (Monogenea). Folia Parasitol 1986, 33:199-206.

Oliver, G. (1981): Etude de Microcotyle labracis VanBeneden et Hesse, 1863 (Monogenea,
Polyopisthocotylea, Microcotylidae) au microscope életronique à balayage. $\mathrm{Z}$ Parasitenkde 65: 235-240.

Paperna, I. (1972a): Contributions the knowledge of the Red Sea No. 32. Monogenetic trematodes from the gills of the Red Sea fishes. Bull. Sea Fishery Res. Stat. Israel, 39: 1-10.

Paperna, I. (1972b): Monogenea of Red Sea fishes I. Monogenea of fishes of the genus Siganus. Proc. Helminthol. Soc. Wash., 39: 33-39.

Paperna, I. (1972c): Monogenea of Red Sea Fishes III. Dactylogyride from littoral and reef fishes. J. Helminthol., 46: 47-62.

Parukhin, A.M. (1989): [Parasitic worms of bottom fishes of the southern seas.] Kiev: Naukova Dumka, 155 pp (In Russian).

Pillai, N.K. (1985): The Fauna of India: Copepod Parasites of Marine Fishes. Zoological Survey of India, India. 900 p.

Purivirojkul1, W. and Areechon, N. (2008): A Survey of Parasitic Copepods in Marine Fishes from the Gulf of Thailand, Chon Buri Province. Kasetsart J. (Nat. Sci.) 42: 40 - 48.

Radujkovic, B.M. and Euzet, L. (1989): Parasite des poisons marins du Monte'ne'gro: Monoge`nes. Acta Adriatica, 30, 51-135.

Ramasamy, R.P. and Hanna, R.E.B. (1985): The surface topography of Gotocotyla secunda and Gotocotyla bivaginalis (monogenea: polyopisthocotylea) from Scomberomorus commerson. Int. J. Parasitol ., 19: 63-69.

Ramasamy, P. and Hanna, R.E.B. (1986a): The surface topography of Bicotyle vellavoli (Monogenea) from the gills of Pampus chinensis. Int. J. Parasitol. 16: 591-594.

Ramasamy, P. and Hanna, R.E.B. (1986b): The surface topography of a monogenean Heterapta chorinemi from the gills of Scomberoides commersonianus. Int J Parasitol 16: 595-600.

Ramasamy, P. and Brennan, G.P. (2000): Ultrastructure of the surface structures and haptor of Empleurosoma pyriforme (Ancyrocephalinae; Monopisthocotylea: Monogenea) from the gills of the teleost fish Therapon jarbua. Parasitol. Res., 86: 129-139.

Ramasamy, R.P.; Brennan, G.P. and Halton, D.W. (1995): Ultrastructure of the surface structures of Allodiscotyla Siacanthi (Polyopoisthocotyla: Monogenea) from the gills of the marine teleost fish, Scomberodies Top. Int. J. Parasitol., 25:43-54.

Randall, J.E. (1995): Coastal fishes of Oman. Australia: Crawford House Publishing Pty Ltd Bathurst, 439 pp.

Sandars, D.F. (1944): A contribution to the knowledge of the Microcotylidae of Western Australia. Transactions of the Royal Society of South Australia, 68, 67-81. 
Sandars, D.F. (1945): Five new microcotylids from fish from Western Australian waters. Journal of the Royal Society of Western Australia, 29, 107-135.

Santos, C.P.; Souto-Padrón, T. and Lanfredi, R.M. (1996): Atriasterheterodus (Lebedev and Paruchin, 1969) and Polylabris tubicirrus (Paperna and Kohn, 1964) (Monogenea) from Diplodus argenteus (Val., 1830) (Teleostei: Sparidae) from Brazil. J Helminthol Soc Wash 63: 181-187.

Shaw, M.K. (1979): The ultrastructure of the clamp wall of the monogenean gill parasite Gastrocotyle trachuri. Z Parasitenkde 58: 243-258.

Shinn, A.P.; Paladini, G.; Rubio-Godoy, M.; Domingues, M.V.; Whittington, I.D.; Bron, J.E. and Mono, D.B. (2013): A web-host for Monogenea. World Wide Web electronic publication. [http://www.monodb.org], last access $(04 / 2013)$.

Smyth, J.D. and Halton, D.W. (1983): The Physiology of Trematodes, Cambridge University Press, Cambridge.

Williams, A. (1991): Monogeneans of the families Microcotylidae Taschenberg, 1879 and Heteraxinidae Price, 1962 from Western Australia, including the description of Polylabris sandarsae n. sp. (Microcotylidae). Systematic Parasitology, 18, 17-43.
Williams, J.B. and McKenzie, J. (1995): Scanning electron microscopy of Polystoma integerrimum (Monogenea, Polystomatidae). Int. J. Parasitol 25: 335-342.

Uyeno, D. and Nagasawa, K. (2010): The copepod genus Hatschekia Poche, 1902 (Siphonostomatoida: Hatschekiidae) from triggerfishes (Pisces: Tetraodontiformes: Balistidae) from off the Ryukyu Islands, Japan, with descriptions of eleven new species. Zootaxa 2478:1-40.

Yamaguti, S. (1954): Parasitic copepods from fishes of Celebes and Borneo. Seto Marine Biological Laboratorypublication 3(3): 375-398.

Yamaguti, S. (1963): Monogenea and Aspidocotylea Systema Helminthum 4, Intersci. Div. Wiley, New York. Sons, 699 pp.

Yoon, G.H.; Al-Jufaili, Freeman, M.A.; Bron, J.E.; Paladini, G. and Shinn, A.P. (2013): Omanicotyle heterospina n.gen.et n.comb. (Monogenea: Microcotylidae) from the gills of Argyops Spinifer (Forsskal) (Teleostei:Sparidae) from the Sea Oman. Parasites\&vectors 6:170.

Zhang, J.-Y.; Yang, T.-B. and Liu, L. (Eds) (2001): Monogeneans of Chinese marine fishes. Beijing: Agriculture Press, 400 pp (In Chinese).

\section{دراسات ميكروسكوبية ضوئية ومسح الكترونى على طفيل المونوجينيا فى أسماك البحر الاحمر (الصرع) بمصر

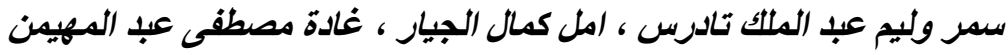 Email: samarhesham@rocketmail.com}

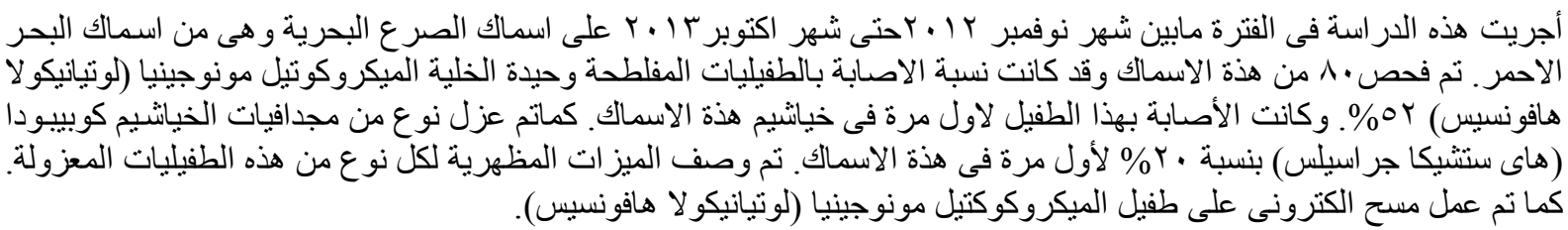

